\title{
Türkiye ve İtalya Eğitim Sistemlerinin Karşılaştırılması*
}

\section{Muhammed Mehmet MAZLUM**}

Öz: Günümüz cumhuriyet rejimlerinin temellerinin atıldığg ülke olarak kabul edilen İtalya; tarihi, uygarlıkları, siyasi gelişmeleri, turizmi, sanayisi, modası, mutfağı, mimarisi, sanatı, edebiyatı ve üniversiteleri gibi pek çok alanda Avrupa'nın en önemli ülkelerinden birisi olmuştur. İtalya'nın sahip olduğu köklü tarih ve kültürel mirasın yanı sıra eğitim alanındaki yüksek gelişmişlik endeksi, bu ülkedeki eğitim sistemini araştırmaya değer kılmaktadır. Alanyazın taraması ile gerçekleştirilen betimsel tarama modelindeki bu çalışmanın amacı; İtalya eğitim sistemini ortaya koymak, Türk eğitim sistemi ile karşılaştırmalı olarak inceleyerek çıkarımlarda bulunmaktır. Bu doğrultuda araştırmada öncelikle İtalya'nın coğrafi, sosyal ve siyasi yapısı açıklanmış, İtalya eğitim sistemi; yönetsel ve okul yapılanması ile süreç boyutu dikkate alınarak incelenmiştir. Buna göre her iki ülkede de eğitimin amaçları büyük ölçüde benzerlik gösterse de yönetsel yapılanma incelendiğinde İtalya'da bölgelere daha fazla yetki devredildiği görülmektedir. İtalya; mesleki liselere katılım ve lise mezun oranı açısından Türkiye’ye göre bariz şekilde farklılık göstermektedir. Ayrıca öğretmen ve okul yöneticilerinin sosyalleşme süreçleri, Türkiye'dekinin aksine İtalya'da büyük ölçüde planlı etkinliklere dayanmaktadır.

Anahtar Kelimeler: İtalya eğitim sistemi, Türk eğitim sistemi, karş1laştırmalı eğitim

\footnotetext{
${ }^{*}$ Çalışmanın hazırlanmasında değerli katkılarından dolayı Prof. Dr. Ali Balcı’ya teşekkür ederim.

*** Arş. Gör., Van Yüzüncü Y1l Üniversitesi, Eğitim Yönetimi ve Teftişi / e-mail: mehmetmazlum7@gmail.com

$\begin{array}{lll}\text { Gönderim:05.04.2017 } & \text { Kabul:25.08.2017 } & \text { Yayın:15.09.2017 }\end{array}$
}




\title{
Comparison of Turkish and Italian Education Systems
}

\begin{abstract}
Italy, where the foundations of contemporary republican regimes have been laid; with its history, civilizations, political developments, tourism, industry, fashion, cuisine, architecture, art, literature and universities have become one of the most important countries in Europe. Italy is worth to investigate with high level prosperity index in the field of education as well as its deep-rooted history and cultural heritage. The aim of this study which is in the descriptive scanning model with literature review is to introduce the Italian education system, to analyze it in comparison with the Turkish education system and make inferences. Accordingly, the geographical, social and political structure of Italy has been explained at first; Italian education system has been analyzed by considering the administrative and school structure and the process aspect. Consequently, although the aims of education in both countries share a great similarity, it is seen that more authority is transferred to the regions in Italy when the administrative structure is examined. Italy's vocational high school attendance and high school graduation rate are obviously different from those of Turkey. In addition, the socialization processes of teachers and school administrators are based largely on planned activities in Italy, unlike in Turkey.
\end{abstract}

Keywords: Italian education system, Turkish education system, comparative education 


\section{Giriş}

Ülkelerin, ihtiyaç duydukları nitelikli insan gücünü yetiştirerek uzun yıllar boyunca varlığını sürdürmeleri; ekonomik, sosyal, politik ve kültürel açıdan kalkınabilmelerine bağlıdır. Tüm alanlarda sürdürülebilir bir gelişimin sağlanabilmesi için en önemli araçlardan birisi de eğitimdir. Bu bağlamda ülkeler, istediği toplumsal düzeni oluşturma ve geleceği inşa etme arzusuyla eğitim etkinliklerini sistematik şekilde düzenleme çabası içine girmektedir. Bunun yanı sıra ülkeler, eğitim sistemlerini geliştirme adına farklı ülkelerdeki eğitim sistemlerini araştırıp analiz etmekte, kendi uygulamaları için çıkarımlarda bulunmaktadır. Bu durum, eğitim sistemlerinin ülkelerarası karşılaştırmalı bir bakış açısıyla incelenmesi gerektirmektedir.

Bu çalışmada İtalya eğitim sisteminin konu edilmesi, Legatum Refah Endeksi’ne göre üst sıralarda yer almasından kaynaklanmaktadır. Düşünce kuruluşu Legatum Enstitüsü tarafından belirlenen gelişmişlik endeksi; ülkelerin ekonomi, sosyal sermaye, eğitim, güvenlik gibi pek çok alana ve genel gelişmişliğe yönelik olarak belirlenmektedir (Legatum Prosperity Index [LPI], 2016). Kuruluşun 2016 yılı verilerine göre İtalya, 149 dünya ülkesi üzerinde genel gelişmişlik endeksinde 32. sırada, eğitim endeksinde 26. sıradadır. Aynı endeksler için Türkiye'nin sıralaması sırasıyla 78 ve 80 'dir. Türkiye'den 54 basamak yukarıda bulunan (LPI, 2016) ve dünyanın en önemli laboratuvarlarından birisi olarak görülen İtalya eğitim sisteminin (Erdoğan, 2003) incelenmeye değer olduğu söylenebilir.

Bu çalışmada, İtalya eğitim sistemini ortaya koymak ve Türk eğitim sistemi ile ilgili çıkarımlarda bulunmak amaçlanmıştır. Alanyazın taraması yoluyla elde edilen bilgiler çeşitli parametreler dikkate alınarak aktarılmıştır. Buna göre öncelikle, İtalya eğitim sisteminin arka planını oluşturan coğrafi, sosyal ve siyasal durumu incelenmiş; ardından İtalya eğitim sistemi, amaç ve politika, yönetsel yapılanma ve okul yapılanması ve eğitim süreci açısından 
incelenmiştir. Çalışmada son olarak Türk eğitim sistemi ile karşılaştırmalar yapılarak çıkarımlarda bulunulmuştur.

\section{İtalya'nın Coğrafi, Sosyal ve Siyasal Durumu}

İtalya, Avrupa'nın güneyinden Akdeniz içlerine doğru kuzeybatı güneydoğukuzeybatı yönünde uzanan, 1836,4 km kara sınırına sahip bir yarımada ülkesidir (Central Intelligence Agency [CIA], 2016). Haritadaki şekli nedeniyle çizme olarak adlandırılan İtalya, kuzeyinde Fransa, İsviçre, Avusturya ve Slovenya ile komşudur. Ülkenin güneybatısında Akdeniz, doğusunda Adriyatik Denizi ve kuzeyinde ise Alp Dağları bulunmaktadır. San Marino ve Vatikan şehir Devletleri ile birlikte İtalya, 301.336 metrekarelik bir yüzölçümüne sahiptir (Eurydice, 2010a, 2010b; İhracatı Geliştirme Etüt Merkezi [İGEME], 2011).

Başkenti Roma olan İtalya'da, yerleşik olarak yaşayan az sayıda Alman, Fransız ve Sloven topluluklar bulunsa da, ülkenin resmi dili İtalyancadır. Bununla birlikte Trentino-Alto Adige (Almanca), Valle d'Aosta (Fransızca) ve Trieste-Gorizia (Slovence) gibi belli bölgelerde vatandaşlar kendi dillerini konuşmaktadırlar. Hristiyanlar, Yehova dini mensupları ve Protestanlar ülke nüfusunun \%80'ini oluşturmaktadır. $\mathrm{Bu}$ oranın tamamına yakınını oluşturan Hristiyan nüfus ise ezici bir üstünlükle Katoliktir. Müslümanlar (800.000 ile 1.000.000 arasında vatandaş), ateistler ve dini bilinmeyenlerin oranı ise \%20'dir. Haziran 2015 itibariyle İtalya'nın nüfusu 61.855.120'dir. Yaşa göre nüfus dağılımına bakıldığında ise 0-14 yaş arası nüfus oranı $\% 13,7 ; 15-24$ yaş arası nüfus oranı $\% 9,7 ; 25-54$ yaş arası nüfus oranı $\% 42,7 ; 55-64$ yaş arası nüfus oranı $\% 12,5 ; 65$ yaş üstü nüfus oranı $\% 21,2$ 'dir. Ülke yaş ortalaması ise 44.8 ' dir (CIA, 2016).

İtalya, çok partili parlamenter sistemle yönetilen demokratik bir cumhuriyettir ve yürütme yetkisi bakanlar kurulunun elindedir. Başbakan, aynı zamanda Bakanlar Kuruluna da 
başkanlık eder. İtalya'da bağımsız yargı sistemi, özerk statüde bulunan Yüksek Hâkimler Kurulu tarafından yürütülür. En yüksek merci olan cumhurbaşkanlığı ise ülkenin bütününü temsil etmektedir (İGEME, 2011). İtalya Parlamentosu, her ikisi de eşit güç ve yetki ile donatılmış Temsilciler Meclisi (Camera dei Deputati) ve Cumhuriyet Senatosundan (Senato della Repubblica [SR]) oluşmaktadır. Temsilciler Meclisi’ndeki 630 milletvekili ile Senato'daki 315 senatör genel seçimlerle beş y1llık süreler için seçilmektedir (Dışişleri Bakanlığı [DB], 2016; Eurydice, 2010b). İtalya'da beşi özerk statüde olmak üzere (FriuliVenezia Giulia, Sardunya, Sicilya, Trentino-Alto Adige ve Valle d'Aosta) 20 yönetim bölgesi bulunmaktadır (EP-Nuffic, 2016). Merkeze bağlı birçok ilçeyi bir araya toplayan vilayetlerden oluşan her bir yönetim bölgesinin kendine özgü mali, yönetsel ve yasal yetkileri vardır ve kendi yetki alanı içinde hizmetlerin sunumundan doğabilecek tüm sorunlardan sorumludur (Türkoğlu, 1998; akt. Yılmaz, 2014). İtalya devlet yapısında, serbest seçimlerle işbaşına gelen bölge (regione), vilayet (provincia) ve belediyeler (comune); tarım, ormancılık, enerji, sağlık, ulaşım, turizm ve çevre sorunları ile sınırlı boyutta ekonomi, ticaret ve vergi toplama konularında yetkilere sahiptir (DB, 2016).

İtalya'da 2015 yılı verilerine göre Gayri Safi Milli Hâsıla 1.819 trilyon dolar, kişi başına düşen yıllık gelir ise 35.800 dolardır (CIA, 2016). Dünyanın büyük 10 ekonomisi arasında bulunan ve Avrupa'nın en büyük dördüncü ekonomisine sahip olan İtalya, küresel ölçekte kendini gösteren ve Avrupa Para Birimi Bölgesinde etkisini gösteren ekonomik krizden en çok etkilenen ülkeler arasındadır ve 2011 yılından bu yana ekonomik krizle mücadele etmektedir. Öyle ki son olarak 2011 y1lında \% 0,4 büyüyen İtalyan ekonomisi, 2012, 2013 ve 2014 yıllarında sırasıyla \% 2,5, \% 1,9 ve \%0,4 oranlarında küçülmüştür (DB, 2016). 2015 yılında ise \%0,8 oranında bir büyüme gerçekleşmiştir. Ayrıca 2014 ve 2015 yılları için işsizlik oranları sırasıyla \%12,7 (gençler arası işsizlik oranı yaklaşık \%40) ve 
\%12,2 seviyelerindedir (CIA, 2016). Küresel ölçekte yaşanan krizin etkisiyle son y1llarda ekonomide gerileyen İtalya'nın, 2015 yılında toparlanma sürecine girdiği görülmektedir.

\section{İtalya Eğitim Sistemi}

Karşılaştırmalı eğitim araştırmalarına öncülük eden Kandel, bu araştırmalar için (İngiltere, Fransa, Almanya, Rusya ve Amerika Birleşik Devletleri ile birlikte) dünyanın en önde gelen laboratuvarlarından birisi olarak gördüğü İtalya Eğitim Sisteminin tarihsel gelişimini ve temel özelliklerini, eğitimin gelişmesinde rol oynayan önemli etmenlerden birisi olarak kabul etmektedir (Erdoğan, 2003). Çalışmanın bu bölümünde; İtalya'da eğitim politikaları ve amaçları, İtalya Eğitim Sisteminin yönetsel ve okul yapılanması ve bu yapıları harekete geçiren süreç boyutu, başlıkları altında incelenmiştir.

\section{Eğitim Politikaları ve Amaçları}

İtalya Eğitim Sisteminin genel amacı; iyi bir temel kültüre sahip, iş dünyasını tanıyan, yeteneklerine göre demokratik topluma tam katılım sağlamış vatandaşlar yetiştirmektir (International Bureau of Education, 1980; akt. Yılmaz, 2014). İtalya Anayasasında 1 Ocak 1948 tarihinde yürürlüğe giren ve günümüzde de geçerliğini koruyan temel eğitim ilkeleri şunlardır (United Nations Educational Scientific and Cultural Organization [UNESCO], 2012; Socrates Comenius [SC], 2005):

- Eğitimde özgürlüğü sağlamak

- Her türde ve düzeyde oluşturulacak eğitim kurumlarını, hiçbir ayrım gözetmeksizin herkesin erişimine açmak

- Yükseköğretimi oluşturan üniversitelerin, akademisyenlerin ve enstitülerin, bağımsız bir şekilde kendi yönetmeliklerini oluşturmalarına imkân tanımak

- Eğitimde özel gereksinimi bulunan bireylere yönelik okul ve eğitim altyapısı oluşturmak 
- Çocuklara devlet güvencesi altında eğitim hizmeti sağlamak

İtalya'da eğitimle ilgili genel hükümlerde kanun yapma yetkisi yalnızca devlete aittir. Ancak İtalya Anayasasının 117. maddesinde, Avrupa Birliği (AB) mevzuatı ve uluslararası yükümlülüklerden doğan kisitlamalar çerçevesinde kanun yapma yetkisi devlete ve bölgelere aittir ibaresi yer almaktadır. Eğitim kurumlarının özerkliğine tabi olmak kaydıyla hazırlanan ortak mevzuat hükümleri ise mesleki eğitim dışındaki tüm eğitim-öğretim faaliyetlerini bağlayıcıdır (SR, 1947). Özetle; İtalya'da eğitime ilişkin genel hükümleri değiştirme yalnızca devletin yetkisinde iken, $\mathrm{AB}$ mevzuatı ve uluslararası yükümlülüklerle çelişmemek kaydıyla bölgesel yönetimler, müşterek yönetmelik hazırlayabilirler.

İtalya'da Eğitim Üniversite ve Araştırma Bakanlığının (Ministero dell’Istruzione, dell’Università e della Ricerca [MIUR]) (8 Kasım 2011 tarihinde) 2012 y1lı için belirlediği politika esaslarında, küresel ekonomi bağlamında eğitim kalitesini sürekli iyileştirmenin; gelişimi, sosyal ve ekonomik büyümeyi sağlamak için en önemli önceliklerden birisi olduğu vurgulanmıştır. Eğitimde sürekli iyileşmeyi hayata geçirmek için Bakanlık; tüm gençlere eşit erişim imkânı sunmaya ve dezavantajlı eğitim bölgelerinde toplumsal hareketliliği sağlamaya yönelik girişimlerde bulunmaktadır (UNESCO, 2012).

\section{Ĕgitim Sisteminin Yapılanması}

Çalışmanın bu bölümünde İtalya Eğitim Sisteminde yönetim yapılanması ve okul yapılanması incelenmiştir. Bu doğrultuda İtalya'da eğitimin yönetsel boyutuyla ilgili olarak yetkili birimlerin görev ve sorumluluklarına; okul yapılanmasıyla ilgili olarak da öğretim kademelerine yer verilmiştir.

Yönetsel yapılanma. İtalya'da kamu yönetimi, uzun bir süre merkeziyetçi anlayışa sahip olsa da 1950'li yılların sonunda eğitim hizmeti ve bazı sorumluluklar kademeli olarak yerel yönetimlere devredilmiş; 15 Mart 1972 tarihinde çıkartılan 59 sayılı kanunla bölgelere, 
illere, ilçelere ve dağ ilçelerine rol ve görevleri bakımından bazı ayrıcalıklar tanınmıştır. 2000-2001 eğitim-öğretim y1lından itibaren tüm okullar yönetim, örgütlenme, eğitim, araştırma, deney yapma ve gelişme konularında çeşitli özerklikler elde etmişlerdir. Buna rağmen okul personelinin yasal statüsü, okul sisteminin değerlendirilmesi, okullara bütçe belirleme, araştırma enstitülerine ve üniversite girişimlerine yönelik plan yapma, yabancı okul ve kurumları denetleme ve finanse etme gibi konulara yönelik politikalar merkezden saptanmaktadır. Ayrıca özel ve resmi tüm okullar devlete bağlıdır (Eurydice, 2010b).

İtalya'da 20 Ocak 2009 yılında çıkarılan yasayla Eğitim Bakanlığı ile Üniversite ve Araştırma Bakanlığı, tek bir bakanlık çatısı altında toplanarak MIUR adını almıştır. Yapıdaki bu değişikliğin amacı, daha etkin ve yeterli bir okul yönetimi sağlamak için hem merkezi yönetimin hem de çevresel bileşenlerin etkinliğini artırmaktır (Eurydice, 2010a). Eğitimle ilgili tüm sorumluluk MIUR'a aittir. MIUR, bölgesel düzeyde Yerel Okul Büroları (Bölgesel Eğitim Müdürlükleri) (Uffici Scolastici Regionali [USR]) ile çalışmaktadır. Ayrıca bölgeler; il düzeyindeki İl Okul Bürolarına (İl Eğitim Müdürlükleri) (Uffici Scolastici Provinciali [USP]) ve belediyelere belli sorumluluklar verme yetkisine sahiptir (Eurydice, 2010b). Diğer bir deyişle İtalya'da eğitim; merkezi düzeyde MUIR, bölgesel düzeyde ise Yerel ve İl Okul Büroları tarafindan yönetilmektedir.

Başkent Roma'da bulunan MIUR'un yönetiminden bakan sorumludur. Bakan; bu süreçte bakan yardımcılarının ve müsteşarların yardımını alır. Ayrıca bu süreçte bakan, şu beş birimle doğrudan işbirliği yapar (Eurydice, 2010b): (1) Bakanlar Kurulu; tüm diğer birimler arasında eşgüdümü sağlayarak politikaların işlevselliği ile bakanlığın yönetim etkinlikleri arasında bağlantı kurar. (2) Yasama Meclisi; bakan sorumluluğundaki konularda yapılan düzenleyici uygulamaları belirlemekle görevlidir. (3) Bakanlık Sekreterliği; Bakanlığın işlevselliğini artıracak çalışmalarda bulunur. (4) Teknik sekreterlik; Bakanlığın benimsediği 
politikaları izlemek ve derinlemesine incelemek için gerekli uzman desteğini sağlamakla görevlidir. (5) Basın Servisi ise; basın gündemini takip etmenin yanı sıra eğitim sistemi ile bilgi kaynakları arasındaki ilişkiyi kurmakla görevlidir.

MIUR, üç temel birimden oluşmaktadır (Eurydice, 2010b): (1) Ĕğitim Biriminin sorumluluğu; okul sisteminin genel yapılanması, değişebilir hedefleri tanımlama ve okul kadrosunun yasal ve ekonomik durumunu belirlemektir. Bu birimde dört genel müdürlük bulunur: (a) Okul Sistemi Yapılanması ve Özerkliği Genel Müdürlüğ̈̈̈; okul kademelerine yönelik etkinlikler, müfredat ve eğitim programları hazırlama, araştırma ve yenilik faaliyetleri ve öğretmen alımı için gerekli sınavlar ve eğitim sisteminin değerlendirilmesi etkinliklerini yürütür. (b) Personel Genel Müdürlüğ̈̈; okullar için gerekli olan yönetici ve öğretim elemanı sayısının belirlenmesi, okul yöneticilerinin işe alınması gibi faaliyetleri yürütür. (c) Öğrenci Katılım, Uyum ve Illetişim Genel Müdürlüğ̈̈; öğrenciler için sosyal politikaların uygulanması, terklerin önlenmesi, özel ihtiyaçları olan öğrenciler de dâhil olmak üzere öğrenci aileleri ve kuruluşları ile iletişimin sağlanması faaliyetlerini yürütür. (d) Yüksek Teknik Ĕ̆itim-Öğretim ve Bölgelerle İlişkiler Genel Müdürlüğ̈̈; teknik-mesleki eğitimin geliştirilmesi, yetişkin eğitimi faaliyetlerini yürütür. (2) Bakanlık Planlama ve İnsan, Finans ve Sermaye Kaynaklarını Yönetme Birimi; mali politika, satın alma, okul yönetiminin insan kaynakları ve bilgi sistemi yönetimi konularında, bünyesine bağlı dört genel müdürlükle hizmet verir. (3) Üniversite, Araştırma ve Üst Düzey Müzik, Sanat ve Dans Eğitimi Birimi; üniversite sistemi için eylem planı yapma, üniversitenin genel düzenini ve finansmanını sağlama, üniversiteyi denetleme ve izleme, Avrupa'daki uygulamalar ve uluslararası yasalar, üniversiteye erişim, araştırma desteği, ulusal, uluslararası ve Avrupa düzeyindeki araştırmaları planlama ve eşgüdümleme gibi sorumluluklar üstlenir. Tüm bu bölümlerin başkanları; bölümleri yönetme, eşgüdümleme ve denetlemede bakana karş1 sorumludur. 
İtalya'da bölgesel düzeyde eğitimden sorumlu olan Yerel Okul Büroları (Bölgesel Eğitim Müdürlükleri), devletin yasalarına bağlı kalarak kendi yasaları ile yönetim sorumluluğuna sahiptir. Yerel Okul Büroları, yerel yönetimlerle birlikte yeni açılacak okulların yapılanmasını, öğrencilerin zorunlu eğitimi tamamlayabilmeleri, mesleki eğitimin özendirilmesi gibi faaliyetlerde bulunur (Erginer, 2009, s.144). Bölgesel yeterlikler içinde bu bürolar ayrıca, minimum performans gerekliliklerini, eğitimde genel düzenlemelere uyulmasını, standartların gözetilmesini ve biçimlendirici eylemlerin etkililiğini, öğrenciler için ulusal politikaların yürütülmesini de önemsemektedir (Eurydice, 2010b). İl Okul Bürolarının (İl Eğitim Müdürlükleri) görevi ise ilkokul ve ortaöğretim düzeyinde, devlet ya da kamu tüm eğitim kurumlarında merkezde yayınlanmış olan yönergelerin uygulanmasını sağlamaktır (Erginer, 2009, 144). Bu bürolar; okullara gerekli olan insan kaynakları konusunda üst birime teklif sunma, okullarda yeniliği ve planlamayı geliştirecek destekleri sağlama, diğer yerel aktörler ile uyumu sağlama, okul ağlarının geliştirilmesi ile ilgili etkinlikleri destekleme; okul binaları kanununun uygulanmasını ve güvenliğini ve göçmen öğrencilerin uyumunu sağlama gibi konularda çalışmalar yürütmektedir (Eurydice, 2010b).

İtalya'da 1997 y1lında çıkarılan eğitim yasasına göre bölgeler düzeyinde 500'den fazla öğrencisi bulunan okullar; eğitim, araştırma ve yapılanmada özerktirler. Bu özerklik tanımına rağmen okullar; madde ve insan kaynaklarını yönetmede, personelinin yasal ve ekonomik durumunu belirlemede ve eğitim programını hazırlamada, MUIR'ın ve yerel düzeydeki İl Okul Bürolarının ölçütlerine bağlı kalmak durumundadırlar. İtalya'da ortaöğretim okulları, Okul Konseyi; ilkokullar ve anaokulları ise Yerel Okul Konseyi tarafından yönetilmektedir. Bununla birlikte ortaöğretimde okul müdürü, ilkokulda ve anaokulunda ise eğitim müdürü, okulun yönetimden sorumludur (Erginer, 2009, 144). 
Okul yapılanması. İtalya'da zorunlu eğitim, 6-16 yaş aralığındaki öğrencilerin eğitimini kapsar. Zorunlu eğitim; beş yıllık ilkokul, üç y1llık alt ortaöğretim ve iki yıllık üst ortaöğretim eğitimi olmak üzere toplam 10 yıldır (Eurydice, 2010a; 2010b) İtalya Eğitim Sisteminde okul yapılanması Şekil 1'de gösterilmiştir.

İtalya Eğitim Sisteminin kademeleri; okul öncesi, ilkokul, ortaöğretim (alt ortaöğretim ve üst ortaöğretim) ve yükseköğretim olmak üzere dört temel kademede incelenebilir. Öğrenciler; 5+3+2 şeklinde tanımlanan zorunlu eğitimi tamamlamak için ilkokul ve alt ortaöğretimde geçirdikleri sekiz yılın ardından üst ortaöğretimin en az iki yılını da tamamlamak zorundadır (EP-Nuffic, 2016; Universita Telematika Leonardo da Vinci [UNIDAV], 2013). Bu bölümde İtalya eğitim sisteminin dört temel kademesinin yanı sıra özel eğitim ve yetişkin eğitimi de incelenmiştir.

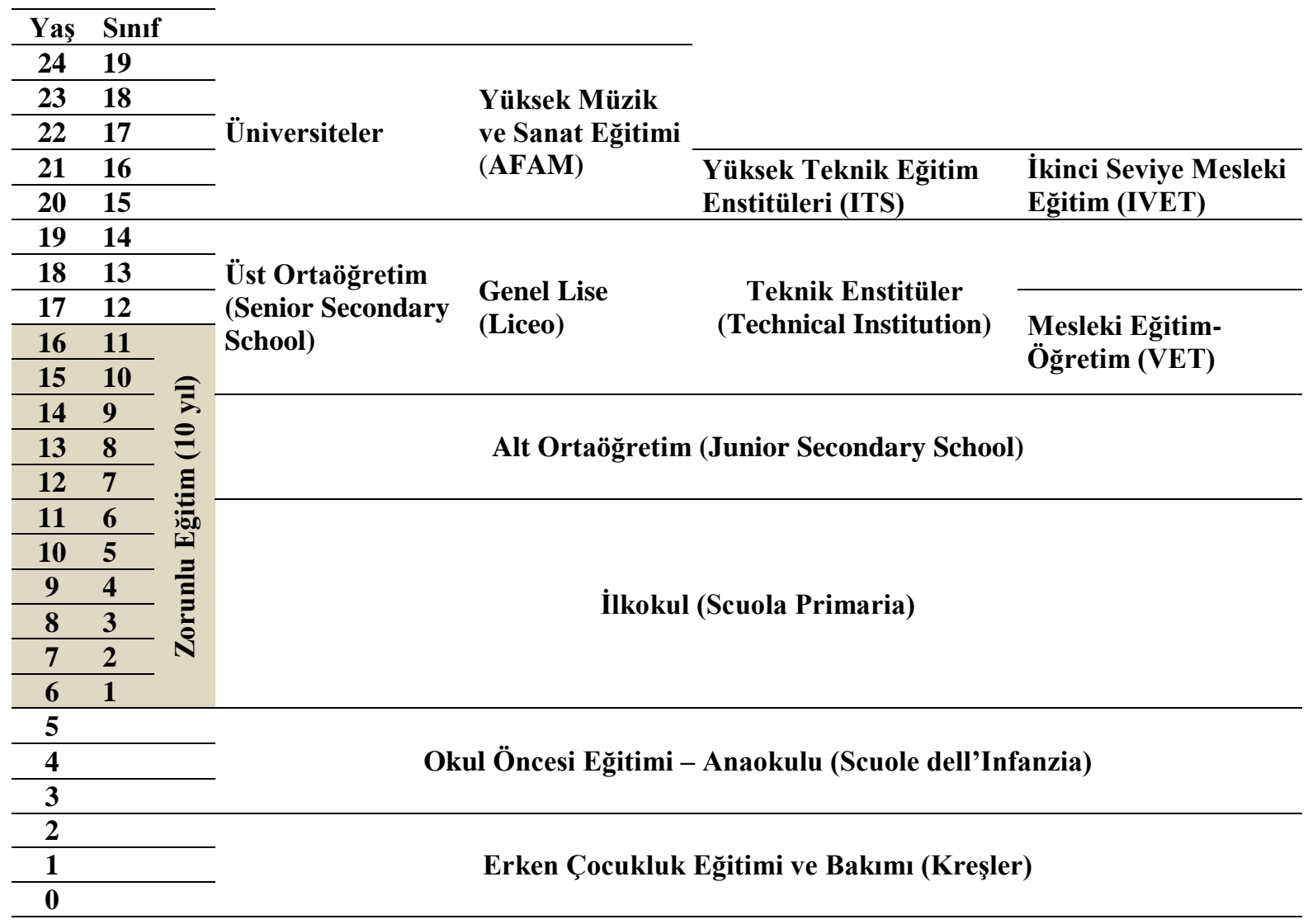


Şekil1. İtalya eğitim sisteminde okul yapılanması (Eurydice, 2010a, 2010b; European Commission [EC], 2015; EP-Nuffic, 2016’dan uyarlanarak geliştirilmiştir).

Okul öncesi ĕgitim. İtalya'da; Montessori, okul öncesi eğitimin mimarı olarak kabul edilir ve okul öncesi eğitimi amaçlayan ilk kurum 1907 yılında açılmıştır (Aktan ve Akkutay, 2014). İtalya'da okul öncesi eğitim, çocukların yaşlarına göre iki kademeli olarak tanımlanabilir: İlk olarak; 3 yaşını aşmamış çocuklar için gündüz bakımevi şeklindeki kreşler mevcuttur. 0-3 yaş arası çocuklar, belediyenin verdiği kreş hizmetinden yararlanabilirler. $\mathrm{Bu}$ kreşler, eğitim sisteminin doğrudan bir parçası olmayıp MIUR'un sorumluluğu dışındadır. İkincisi ise; çocukların 3 yaşından itibaren katılabildikleri anaokullarıdır (Scuole dell'Infanzia). Bu okullar, eğitimin ilk basamağı olarak kabul edilir. 3-6 yaş aralığındaki çocukların katıldıkları bu anaokulları, MIUR'un sorumluluğundadır ancak İtalya'da okul öncesi eğitim zorunlu değildir (Eurydice, 2013; EP-Nuffic, 2016; Milli Eğitim Bakanlığ1 [MEB], 2010; UNIDAV, 2013). Diğer bir deyişle; erken çocukluk eğitimi ve bakımı için kreşler 0-3 aralığındaki çocuklara, okul öncesi eğitim için de anaokulları 3-6 yaş aralığındaki çocuklara hizmet vermektedir ve her ikisi de zorunlu değildir. Ayrıca eğitimin başlangıcı, 3-6 yaş aralığındaki çocuklara hitap eden okul öncesi eğitim olarak kabul edilir.

Daha çok yerel otoritelerin ya da özel sektörün girişimleri ile (\%93 oranında) hizmet veren kreşler (0-3 yaş için), tüm yıl ve tam gün eğitimin yanında esnek zamanlı ya da yarı zamanlı bakım olanakları sunmaktadır. 3-6 yaş aralığındaki çocukların eğitimini kapsayan anaokulları (Scuole dell'Infanzia) ise çok büyük ölçüde kamu kaynaklıdır. Zira İtalya'da 1968 yılında çıkarılan bir yasa ile okul öncesi eğitim (3-6 yaş için), İtalyan vatandaşlarının çocukları için bir kamu hizmeti haline gelmiştir (Toprak, 2009). Anaokullarında karma eğitim yapılır ve genelde; üç farklı yaş grubundaki (3, 4 ve 5 yaş) çocuklar için ayrı sınıflar bulunmaktadır. Bununla birlikte bu kurumlarda olanaklar dâhilinde farklı yaş grubundaki 
çocuklar bir arada eğitim görebildiği gibi bir okul, yalnızca bir yaş grubundan oluşan öğrencilere de hizmet verebilir (Eurydice, 2010b).

İlkokul (scuola primaria). İtalya'da ilkokul, 6-11 yaş aralığındaki öğrencilerin eğitimini kapsar ve 10 yıllık zorunlu eğitimin ilk bölümünü oluşturur. 2009-2010 eğitimöğretim yılından itibaren; bulunulan yıl içinde 30 Nisan itibariyle altı yaşına basanlar veya 31 Aralıkta 6 yaşına basanlar (ailelerin isteğine bağlı), ilkokula kayıt yaptırmak zorundadır. Bu kararla ailelerin, çocuklarının akademik kariyerine ilişkin belirleyici bir rol oynamalarına imkân tanınmıştır (Eurydice, 2010b).

İlkokul eğitimi; devlet okullarının yanı sıra, yasaca tanınmış özel okullarda da verilebilir (Eurydice, 2013; EC, 2015; EP-Nuffic, 2016). Beş yıllık ilkokul eğitiminin ilk yılı, anaokulundan gelen öğrencilerin hazırlık aşaması olarak tasarlanmıştır. Bunun ardından, birbirini izleyen iki yıllık iki devre şeklinde eğitim tamamlanır (Eurydice, 2010a, 2010b).

Ortaöğretim. İtalya Eğitim Sisteminde ortaöğretim, iki aşamalı olarak yapılandırılmıştır: Birincisi; ilkokul sonrasında zorunlu olarak devam edilen ortaöğretimin 1.devresidir (alt ortaöğretim). İkincisi ise öğrencilerin iki en az iki y1l boyunca devam etmek zorunda oldukları ortaöğretimin 2.devresidir (üst ortaöğretim/lise) (SC, 2005; Eurydice, 2013). Ortaöğretimi oluşturan bu iki eğitim kademesi aşağıda açıklanmıştır.

Ortaöğretim 1. devre (alt ortaöğretim) (scuola media inferiore/junior secondary school). Ortaöğretimin bu kademesi, 11-14 yaş aralığındaki öğrencilerin 3 yıllık zorunlu eğitimini kapsar (MEB, 2011). Beş y1l süren ilkokulla birlikte alt ortaöğretim, İtalya Eğitim Sistemindeki birinci eğitim döngüsünü oluşturur (UNIDAV, 2013). Kamu ve özel girişimlerle sunulan alt ortaöğretim; çocukların özgürce çalışmasını teşvik ederek sosyal 
etkileşime yönelik tutumlarını güçlendirmeyi amaçlamaktadır. Üç yıllık eğitim sürecinin son yılı, üst ortaöğretime diğer bir ifade ile liseye geçiş için rehberlik çalışmalarına yönelik tasarlanmıştır (Eurydice, 2010a). Üçüncü yılın sonunda öğrenciler, eğitim sistemindeki ilk döngüyü (ilkokul + alt ortaöğretim) tamamlamış olurlar (MEB, 2010).

Ortaögretim 2. devre (üst ortaöğretim, lise) (scuola secondaria di secondo grado'/senior secondary school). Üst Ortaöğretim (lise) eğitimi, İtalya Eğitim Sisteminin ikinci döngüsünü oluşturur. Bu döngünün ilk iki yılı, zorunlu eğitim kapsamındadır. Öğrencilerin, ikinci eğitim döngüsünü tamamlamak için üç farklı yolu bulunmaktadır (Eurydice, 2010a, 2010b; UNIDAV, 2013; EP-Nuffic, 2016): (1) Eğitim bölgeleri tarafından örgütlenen ve üç-beş yıllık eğitimi kapsayan Mesleki Eğitim-Öğretim Sistemi (Vocational Education and Training System [VET]). (2) Beş yıllık bir eğitimin verildiği devlet liseleri (Genel Lise, Liceo). (3) Beş yıllık eğitim veren devlet okulları olan Teknik Enstitülerdir (Technical Institution).

VET; Temel (Birinci Seviye) Mesleki Eğitim (First-level Initial Vocational Training) ve İkinci Seviye Mesleki Eğitim (Second-level Initial Vocational Training [IVET]) olmak üzere iki şekildedir. Temel Mesleki Eğitim, eğitim bölgelerince akredite edilmiş mesleki eğitim kurumları/acenteleri tarafından verilen üç yıllık (14-17 yaş grubu) eğitimdir. Ayrıca okulların organize ettiği mesleki eğitim ünitelerine göre hareket eden eğitim kursları da bu eğitimi verebilirler. Üç yıllık temel eğitimin ardından eğitim süresi, çıraklık eğitimi kapsamında iki (bazı bölgelerde üç) yıla kadar uzatılabilir. Kurumların akredite olabilmeleri için lojistik altyapısının ve yönetim kapasitesinin, ekonomik durumunun, mesleki yeterliğinin, etkinliklerdeki yeterliği ve etkililiğinin ve çevredeki sosyal sistemlerle ve üretim sistemleriyle ilişkilerinin yeterli düzeyde olması 
gerekmektedir. Akreditasyon için gerekli olan asgari ölçütler MIUR tarafından belirlenirken, gereksinimler ve usuller bölgelerce belirlenmektedir (Eurydice, 2010b).

IVET Mesleki Eğitime ise üst ortaöğretim düzeyinde genel lise diplomasına sahip ya da temel mesleki eğitim derecesindeki yeterliklere sahip 20-23 yaş aralığındaki öğrenciler katılabilmektedir. IVET temel bir eğitim kademesi olmaktan çok, üst ortaöğretim ile yükseköğretim kademeleri arasında, ön lisans düzeyinde yer almaktadır. Eğitimin bu kademesi İtalya’da, lise sonrası/yükseköğretim öncesi eğitim-öğretim (postsecondary non-tertiary education and training) olarak anılmaktadır. $\mathrm{Bu}$ eğitim kademesinde IVET ile birlikte Yüksek Teknik Eğitim Enstitüleri (Istituti Tecnici Superiori [ITS]) de yer almaktadır. ITS, iki yıl süren (en fazla üç yıla kadar uzatılabilen) eğitimlerle; enerji verimliliği, yaşamdaki yeni teknolojiler, sanatsal ve kültürel etkinlikler için teknolojinin kullanımı gibi alanlardan birisine yönelik üst düzey diploma alma imkânı sunmaktadır. Ayrıca bu eğitim, talep gelmesi halinde bir yılı geçmemek koşuluyla eğitim bölgelerinde de verilebilmektedir (Eurydice, 2010b).

İtalya'da genel liselerin amac1, öğrencileri yükseköğretime hazırlamaktır. Teknik enstitüler ise öğrencileri tarım, hayvancılık, muhasebe, endüstri ve turizm gibi çeşitli meslek alanlarına hazırlamayı amaçlar. Genel liselerde ve teknik enstitülerde eğitim-öğretim beş yıl sürer ve 14-19 yaş aralığındaki öğrencilere hitap eder. Bunun tek istisnası olan sanat liselerinde eğitim-öğretim dört yıl sürer ve ardından bir yıl boyunca uzmanlık eğitimi verilir (Eurydice, 2010b). İtalya'da 2010 yılında yapılan bir eğitim reformu ile (Riforma Gelmini) lise türü artırılarak öğrenciler için daha çeşitli uzmanlık alanları getirilmişstir. 2010-2011 eğitim-öğretim yılından itibaren İtalya'da altı lise türü bulunmaktadır (EP-Nuffic, 2016): (1) Bilim Lisesi (Liceo Scientifico); uygulamalı bilim de dâhil olmak üzere bilim programlarını içerir. (2) Klasik Lise (Liceo Classico); beşeri bilimleri ve eski dilleri içerir. (3) Dilbilim 
Lisesi (Liceo Linguistico); modern diller ile Latince ve İtalyanca eğitimi verilir. (4) Sanat Lisesi (Liceo Artistico); grafik, tasarım, heykel gibi toplamda altı uzmanlık alanını içeren sanat okuludur. (5) Müzik ve Dans Lisesi (Liceo Musicale e Coreutico); müzik ve dans ile ilgili programları içerir. (6) Beşeri Bilimler Lisesi ( Liceo Delle Scienze Umane); sosyoekonomi programlarını içeren okullardır. Teknik enstitülerde ise öğrenciler, iki uzmanlık alanı içeren ekonomi programını ya da dokuz uzmanlık alanı içeren teknik programı seçebilirler (EP-Nuffic, 2016).

Yükseköğretim (tertiary education/ higher education). İtalya Eğitim Sisteminde yükseköğretim; üniversitelerde ve Yüksek Müzik ve Sanat Eğitim Kurumlarında (Alta Formazione Artistica e Musicale [AFAM]) yapılır (Eurydice, 2010b, 2013). Bunun yan1 sıra; iki yıllık eğitim veren Arşivleme, Paleografi ve Kültürel Diploması Okulları ile üç yıllık eğitim veren Yükseköğretim Çevirmen Enstitüleri de bulunmaktadır. Ayrıca daha önce bahsedilen Yüksek Teknik Eğitim Enstitüleri (ITS) de yükseköğretimin bir parçası kabul edilir (EP-Nuffic, 2016).

İtalya’da üniversitelerin özerkliğine yönelik olarak 3 Kasım 1999 yılında çıkarılan ve 2001/2002 eğitim-öğretim yılından itibaren uygulanmaya başlayan reformlar, üniversite öğrenimine yönelik yeni bir düzenleme öngörmüştür. Buna göre İtalya'da üniversite eğitimi üç eğitim döngüsünü içerir: Birinci döngü, birinci düzey eğitim programı olan üç yıllık corsi di laurea eğitimidir. İkinci döngü, özel mesleki uzmanlık eğitimi programlarını içeren ve iki y1l süren corsi di laurea specialistica eğitimidir. Üçüncü döngüde yer alan doktora araştırma programı Dottorato di Ricerca ise uzmanlaşma derecesinin elde edilmesini sağlayan programdır ve üç yıllık bir eğitimi kapsar (Eurydice, 2010a, EP-Nuffic, 2016).

İtalya yükseköğretiminde üç döngüden oluşan sistemi öngören düzenlemeler, Bologna Bildirisi sonrasında ortaya konulmuştur. Bologna bildirgesi 1999 yılında İtalya'nın 
Bologna şehrinde 29 Avrupa ülkesinin eğitim bakanları ya da ilgili bakanlık temsilcilerinin imzaladıkları ve ilan ettikleri ilkeler bildirgesidir. Bu bildirge; ulusal ve Avrupalı çerçevesini belirleme, ortak hareket etme ve birlikte yürümeye mutabık olma özellikleri taşıdığından yükseköğretimde bir milat olarak görülür (Korkut ve Mızıkacı, 2008). Bologna bildirgesi ile kalite güvencesinde Avrupa boyutunun oluşturularak yükseköğretimde Avrupa boyutunun güçlendirilmesi, kolay anlaşılır ve karşılaştırılabilir bir derece sisteminin uygulanması, lisans ve lisansüstü olmak üzere iki kademeli bir sistemin uygulanması, ortak bir kredi sistemi oluşturulması ve öğrenci/öğretim üyesi hareketliliğinin özendirilmesi ve teşvik edilmesi hedeflenmiştir (Kansu-Yetkiner, 2012).

İtalya Eğitim Sisteminde AFAM, üniversite dışı yükseköğretim (non-university higher education) olarak yer alır. Toplam beş yıllık bir eğitimin verildiği AFAM'da eğitimin ilk üç yılı birinci döngüyü, sonraki iki yılı ikinci döngüyü oluşturur. Yasal olarak tanınmış eğitim kurumu olan AFAM, kendi yapısını, yönetmeliğini ve örgütlenmesini oluşturma yetkisine sahip olan çeşitli akademilerden oluşur (Eurydice, 2010a). Bunlar; Güzel Sanatlar Akademisi (boyama, heykel, dekorasyon ve sahne dekoru eğitimleri), Yüksek Sanat Enstitüleri (grafik tasarım alanında verilen özel eğitim), Ulusal Drama Akademisi (tiyatro oyunculuğu ve yönetmenliği eğitimi), Konservatuarlar (müziği öğreten uygulamalı sanat eğitimi) ve Ulusal Dans Akademisidir (dansçı, solist ve koreograf eğitimi) (Eurydice, 2010a; EPNuffic, 2016). Bu akademilerin haricinde Ulusal Sinema Okulu, Restorasyon Merkez Okulu, Mozaik Restorasyon Okulu, Kıymetli Taş İşleme Okulu gibi diğer bazı eğitim kurumları mevcuttur; ancak resmi bir eğitim derecesi olarak tanınmazlar. Yalnızca üniversiteler ve AFAM, yükseköğretimde lisans sertifikası veren eğitim kurumlarıdır (Eurydice, 2010a). 
Özel eğitim (kaynaştırma eğitimi). İtalya'da 1970'li y1lların ortasından günümüze engelli çocuklar, eğitim kademelerinde diğer öğrenciler ile birlikte uyum içinde eğitim görmektedir. İtalya'da, bazı özel okulların dışında engelli çocuklar için ayrı bir okul bulunmamaktadır. İtalya'da 1992 yılında çıkarılan eğitim yasası; engelli çocukların gündüz bakımevlerine, anaokullarına ve üniversite dâhil her okul kademesinin tüm sınıflarına uyumunu öngörmektedir (Eurydice, 2010b). İtalya'da özel eğitim gereksinimi duyan çocukların neredeyse tamamı (\%99) normal eğitim bünyesindedir ve uygulamada karşılaşılan en büyük sorun öğretmenlerin bu konuda ne yapacaklarını bilmemeleridir (Kuz, 2001; akt. Sart, Ala, Yazlık ve Y1lmaz, 2004)

Yetişkin eğitimi. İtalya'da yetişkin eğitimi, yaşam boyu öğrenme kapsamında değerlendirilmekte ve 10 yıllık zorunlu eğitimini tamamlamış (16 yaşından büyük) tüm yetişkinlerin erişimine açıktır. Yetişkin eğitimi, MUIR bünyesinde kurulan bölgesel düzeydeki Sürekli Eğitim Merkezleri (Centri Territoriali Permanenti [CTP]) aracılı̆̆ıyla gerçekleştirilir (Eurydice, 2010b). Ayrıca İtalya'da birçok özel dernek ve kurum yetişkinlerin ve gençlerin kültürel gelişimleri ile teknik ilerlemeleri için genel ve teknik konularda kurslar düzenlemektedir (Türkoğlu, 1998; akt. Eğitimi Araştırma ve Geliştirme Dairesi Başkanlığı [EARGED], 2009). Yetişkin eğitimi; CTP ve üst ortaöğretim okullarının, akşam okullarında yetişkinlere yönelik; ilkokul ve alt ortaöğretim tamamlama, zorunlu eğitimi tamamlama, üst ortaöğretimi tamamlama, fonksiyonel okuryazarlık, göçmenler için okuryazarlık fırsatları sunmaktadır. Yetişkin eğitimi için katılımcılar herhangi bir ücret ödememekte, masraflar devlet, bölgeler, yerel otoriteler ile kamu ve özel kuruluşlar tarafından karşılanmaktadır (Eurydice, 2010b). 


\section{İtalya Eğitim Sisteminin Süreç Boyutu}

İtalya Eğitim Sisteminin yönetsel ve okul yapılanmasını harekete geçiren süreç boyutunda; eğitim-öğretim süreçleri, öğretmenlerin ve yöneticilerin yetiştirilmesi, eğitim denetimi ve eğitim finansmanı başlıkları altında incelenmiştir.

Ĕ̆itim-öğretim süreçleri. İtalya Eğitim Sisteminde 0-3 yaş aralığındaki çocuklara eğitim veren kreşlerde oyun ve sosyal ilişkilere önem verilmekle birlikte eğitim hizmeti, bölgelerin ihtiyacına göre farklılaşabilmektedir (Toprak, 2009). Anaokullarında ise eğitim, (bölgelere göre farklılıklar gösterebilse de) resmi olarak 1 Eylül'de başlar ve 30 Haziran'da sona erer. Tatiller; Noel tatili, Paskalya tatili ve yaz tatilinden oluşmaktadır (EC, 2015). 2009 yılında yapılan değişiklikle her bir sınıfta bulunabilecek öğrenci sayısı en az 15 (okul öncesinde 18), en fazla 25 olarak belirlenmiştir. Ayrıca kaynaştırma öğrencisi (disabled) bulunan sınıflarda öğrenci sayısı üst sınırı 20; okulun genellikle dağlarda ve küçük adalardaki ücra yerlerde konumlandığı durumlarda ise öğrenci sayısı alt sınırı 10 olarak belirlenmiştir (Eurydice, 2010b).

İtalya'da ilkokullarda eğitim-öğretim, her yıl 1 Eylülde başlamakta ve 30 Haziranda sona ermektedir (EC, 2015). İlkokul, devlet okullarında ücretsizdir. Öğrencilerin her türlü ders kitabı ihtiyacı ile taşımacılık ve yemek masrafları belediyelerce karşılanmaktadır. Ancak bazı istisnalar dışında ailelerin okula maddi katkısı beklenmektedir. İlkokulda sınıflarda en az 10 en fazla 25-27 öğrenci eğitim görebilmekte; ancak bir kaynaştırma öğrencisinin bulunduğu sınıfta öğrenci sayısı 20'yi geçememektedir (Eurydice, 2010b). İlkokullardaki dersler; İtalyanca, Matematik, Bilim, Tarih/Coğrafya/Sosyal Bilimler, Sanat, Müzik, Beden Eğitimi, Bilgisayar ve seçmeli bir derstir (Katolik Din Eğitimi). Beş şube için toplam ders süresi 146 saattir ve programda İtalyanca (30 saat), Matematik (30 saat) ve Tarih/Coğrafya/Sosyal Bilimler (25 saat) 
derslerine ağırlık verildiği görülmektedir. Ders saatleriyle ilgili 2004 yılında yapılan değişiklikle, zorunlu ders saati her y1l için 891 saat, her hafta için ortalama 27 saat olarak belirlenmiştir (MEB, 2010). Öğrenciler, sıfır ila 10 puanları arasında değerlendirilmektedir (Eurydice, 2010b). Beş yıllık ilkokul eğitiminin sonunda öğrencilere licenza elementare belgesi verilmekte ve öğrenciler doğrudan bir üst eğitim kademesine geçirilmektedir (MEB, 2011).

İtalya'da alt ortaöğretim, her eğitim-öğretim yılının eylül ayının başı ile haziran ayının ortaları arasındaki süreci kapsamaktadır (Eurydice, 2010b; EC, 2015). Üç yıl süren alt ortaöğretim eğitimi sonunda öğrencilere Licenza di Scuola Media diplomas1 verilmektedir (MEB, 2011). Üçüncü yılın sonunda öğrenciler, eğitim sistemindeki ilk döngüyü (ilkokul + alt ortaöğretim) tamamlayarak ikinci döngüye başlamak için Ortaokul Bitirme Devlet Sinavina (The First-Cycle Leaving State Exam) girerler. Öğrencilerin, sınava girebilmeleri için eğitim-öğretim yılının en az dörtte üçü oranında okula devam etmiş olmaları ve her bir dersinin 10 üzerinden en az 6 puan olması şartı aranır. Sınav değerlendirmesinde de 10 üzerinden en az 6 puan alan öğrenciler başarılı sayılır ve öğrencilere diplomaları (diploma di licenza conclusiva del primo ciclo di istruzione) verilir (MEB, 2010). Öğrenci bir ya da daha fazla dersin sınavından geçer not alamadığ takdirde ikinci döngüye geçişi askıya alınarak, eğitim-öğretim döneminin başında başarısız olduğu derslerden yeni bir değerlendirilmeye tabi tutulur (Eurydice, 2010b).

İtalya'da zorunlu eğitim kapsamında yalnızca üst ortaöğretim okullarında kayıtta cüzi bir ücret alınmaktadır. Bu okullarda, gerekli görüldüğü takdirde ailelerden, laboratuvar malzemeleri için ya da kaynaşma ve spor etkinlikleri düzenlemek için maddi destek talep edilebilir. Bu okullarda öğrenci sayısı 25-28 sayıları ile sınırlandırılmıştır. Üst ortaöğretimde ortak bir eğitimin verildiği ilk üç yılın ardından öğrenciler, bölümlere göre 
farklı sınıflara yönlendirilir. Öğrencilerin değerlendirilmeleri, üç ya da dört ayda bir yapılır. Bunun yanında klasik olarak dönem sonu ve yılsonu değerlendirmeleri de vardır (Eurydice, 2010b). İtalya'da beş y1llık üst ortaöğretim eğitiminin sonunda öğrencilere Diploma di Maturita verilir (MEB, 2011). Bu diploma ile birlikte öğrenciler bitirme sınavına (esame di maturità) girerler. Öğrencinin bu eğitim dönemi boyunca aldığ krediler, 25 puana kadar ulaşabilen bir ölçüde sınav puanına katkı sağlar. Meslek liselerinde ve sanat liselerinde ise farklı olarak; başarılı bir eğitimin sonunda alınacak yeterlilik sertifikası ile master of art sertifikası, sınavda başarılı olmaları durumunda öğrencilerin iş piyasasına adım atmalarını sağlar (Eurydice, 2010b).

Lise sonrası üniversite öncesi eğitim kademesinde yer alan IVET'te; üst ortaöğretim diplomasına veya birinci seviye mesleki yeterliliklere sahip olan 20-23 yaşlarındaki öğrenciler, özellikle bölgenin üretim ihtiyacı olan alanlarda bir yıl içinde toplamda 400-600 saat süren eğitime katılırlar ve yerel düzeyde uzmanlaşırlar. Sınıflar genelde 20 kişi ile sınırlıdır ve bir sınıfın açılabilmesi için en az 12 öğrenci bulunması gerekir. Değerlendirmeler, tamamlanan her eğitim bölümü sonunda anketler ve yazılı sınavlar şeklinde yapılır. Öğrenciler, final sınavından önce alan uzmanları, ticaret odası ve bölge temsilcilerinin değerlendirmesine tabi tutulurlar (Eurydice, 2010b).

Yüksek Teknik Eğitimde yaş sınırı yoktur ve eğitim dört (1800-2000 ders saati) ya da altı dönem (ilaveten 800-1000 ders saati) şeklinde devam eder. Teknik eğitim önemsendiğinden, öğrencilerin eğitim sürelerinin \%30’u şirketlerde iş başı eğitim ile geçmektedir. Alınan eğitim sonrasında öğrenciler; aldıkları kredilerin yanında özel kurul denetçileri, okul temsilcileri, üniversite uzmanları ve mesleki eğitim uzmanları ve iş piyasası temsilcilerinin oluşturduğu bir komisyon tarafından değerlendirilir. Bunun 
sonucunda başarılı sayılan öğrenciler, üst düzey tekniker ya da uzman diploması alırlar (Eurydice, 2010b).

İtalya'da üniversiteler; yönetmeliklerini, yönetim kurullarını, eğitim ve araştırma yapılarını oluşturmakta özerktir. Üniversitede lisans eğitimine başlamak için öğrencilerin, bir üst ortaöğretim diplomasına (Diploma di Superamento dell'esame) (Sağlam, 2004) ya da yurt dışı ülkelerden elde edilmiş geçerli bir diplomaya sahip olmaları gerekmektedir. Üniversiteye kayıt sırasında öğrenciler, ailelerinin gelir durumuyla orantılı olarak kayıt ücreti ödemektedir. Üniversiteler, alacakları öğrenci sayısını belirlemekte serbesttirler (Eurydice, 2010b).

İtalya'da üç döngüden oluşan üniversite eğitiminin ilk döngüsü (üç yıl) genel yeterliklerin kazanıldığı ve toplamda 180 krediden oluşan dönemdir (Eurydice, 2010b). Bologna süreci ile birlikte kabul edilen üç döngülü sistem ile birlikte lisans öğreniminin dört yıldan üç yıla inmesine, akademisyenlerin \%42'si, bu sistemin eğitimi geliştirdiği iddiasını reddederek karşı çıkmış ve eski sistemin devam etmesini talep etmiştir. Ayrıca birçok üniversiteden öğrenciler de çeşitli zamanlarda protesto gösterileri yapmışlardır (Çelik, 2012). Üç döngülü bu sistemin ikinci döngüsü, iki yıllık bir eğitimi içeren 180 kredilik alan uzmanlığı eğitimini kapsar. Öğrenciler bu aşamada 60 kredilik daha ders alarak yüksek lisans (master) eğitimini tamamlamış olurlar. Yüksek lisans programlarına kabul edilmenin şartı ise öğrencilerin lisans ya da üç yıllık bir üniversite derecesine sahip olmaları ya da yurt dışı ülkelerden elde edilmiş geçerli bir diplomaya sahip olmalarıdır. Bu kademede geçme notu 110 üzerinden en az 66'dır. Öğrencilerin lisans ya da yüksek lisans diplomasına sahip olabilmeleri için ayrıca, araştırma kurulunun önerdiği bir konuda ya da laboratuvar çalışması ya da çalıştay sonucunda hazırlayacakları bir rapor sunmaları gerekmektedir. Üniversite 
eğitiminin üçüncü döngüsü ise üç yıllık eğitimi kapsayan doktora çalışmalarıdır (Eurydice, 2010b).

Üniversite ile benzer şekilde; üniversite dışı yükseköğretim sayılan AFAM'a kayıt olmak için öğrencilerin üst ortaöğretim diplomasına sahip olmaları gerekmektedir. Ayrıca her bir üniversitenin ve AFAM'ın, kayıt kabulü için kendi özel şartlarını oluşturma yetkisi de bulunmaktadır (Eurydice, 2013; Sağlam, 2004). AFAM'larda eğitim ücreti, her bir eğitim kurumunun kendi belirlediği oranda tahsis edilir. Devlet, öğrenci bursu adı altında çok sınırlı bir oranda maddi katkı sağlar ve bazı alanlarda AFAM'ları vergiden muaf tutar. Öğrenciler, ders kitapları için ücret öderler; ancak dersteki alıştırma ve tezler için kullanılan materyallerin masrafi, kurumun kendisi tarafından ödenir (Eurydice, 2010b).

Öğretmenlerin yetiştirilmesi. İtalya'da tüm öğretmenlerin eğitimi üniversitelerde yapılmaktadır. Adayların, öğretmen olabilmeleri için beş yıllık üniversite sertifikasına sahip olmaları gerekmektedir (laurea magistrale). Okul öncesi ve ilkokul düzeyindeki öğretmenler için 600 saat hizmet-içi eğitimi de kapsayan beş y1llık bir eğitim; ortaöğretim düzeyindeki öğretmenler içinse üç yıllık üniversite eğitiminin ardından alınacak iki yıllık bir uzmanlık eğitimi ile birlikte bir yıl da hizmet-içi eğitim (stajyerlik) şartı aranmaktadır. İtalya'da öğretmenlik kamu okullarında sözleşmeli ya da kadrolu olarak yapılmaktadır (Eurydice, 2010b).

İtalya'da öğretmenlerin, görev yaptıkları süre boyunca gelişimi hedeflendiğinden, hizmet-içi eğitime de önem verilmektedir. İtalya Ortak Ulusal İş Sözleşmesinin okullarla ilgili bölümü, öğretmen eğitimini insan kaynakları gelişimi açısından oldukça önemli görmektedir. Öğretmenlere; bilişim ve iletişim teknolojileri, yönetim ve okul geliştirme gibi konularda verilen hizmet-içi eğitime yönelik olarak yükseköğretim kurumlarının, öğretmen derneklerinin, özel sektör eğitim merkezlerinin ya da bazı sivil toplum 
örgütlerinin, akreditasyon ve değerlendirme çalışmaları yürütmeye yetkisi vardır. $\mathrm{Bu}$ yetkiye sahip olmayan tek organ ise kamuda yer alan hizmet içi eğitim merkezleridir (Eurydice, 2006)

Yöneticilerin yetiştirilmesi. İtalya'da yükseköğretim haricinde tüm eğitim seviyelerindeki okullar, müdürler (dirigenti scolastici) tarafından yönetilir. Müdürlerin görev ve sorumlulukları, Genel ve Yönetsel İşler Genel Müdürlüğü (Direttore dei servizi generali e amministrativi, The Director for General and Administrative Services) ve Yönetsel-TeknikYardımcı Personel Müdürlüğü (administrative-technical-auxiliary) tarafından belirlenir (Eurydice, 2010a; 2010b).

İtalya'da, ihtiyaç duyulan müdürlük kadrosu için her üç yılda bir ilana çıkılır. Müdürlerin işe alınmaları bölgedeki özel değerlendirme birimlerinin sorumluluğundadır. $\mathrm{Bu}$ birim; 2007 yılında yürürlüğe giren ve 2008 yılında yapılan bir takım düzenlemelerle son halini alan işe alma sürecini yönetmektedirler. Bu birimin görevleri sırasıyla; rekabet yaratma, boş kadroları doldurma, devlet okullarının ve yatılı okulların öğretmen ve yönetici kadrolarına açık erişimi sağlama, en az beş yıldır kadrolu öğretmenlik yapıyor olma, en az bir testi geçen adayları mülakata alma, adayların yeterliklerini değerlendirerek sıralama yapma ve adayı seçme şeklinde gerçekleştirilir. Seçilen aday, dört ayı geçmemek şartıyla bir eğitim ve staj sürecinde alınır ve bunun sonunda adayla sözleşme yapılarak göreve başlatılır (Eurydice, 2010b). İtalya'da merkezi yönetim tarafından ataması yapılan müdürler için sürekli eğitim hizmetinin verilmediği, kısmen kurumsallaşmış bir yönetici yetiştirme sürecinin işletildiği görülmektedir (Çelik, 1995).

Eğitim denetimi. İtalya Eğitim Sisteminde eğitim kurumlarının denetimi, esas olarak iç denetim ve diş denetim şeklinde gerçekleşir. Akademik Hizmetler Dairesi, eğitim kurumlarının iç denetiminden sorumludur ve özdenetimi teşvik eder. Eğitim, yönetsel işler ve 
çevre ile ilgili aileler, okul personeli ve öğrencilere yönelik araştırmalar yaparak kaliteyi ve standardı belirlemeye çalışır. Okulların dış denetimi içinse Ulusal Eğitim Sistemini Değerlendirme Kurumu (National Institute for the Evaluation of the Educational System [INVALSI]) görevlidir. 2003 yılında çıkarılan eğitim yasası ile eğitim-öğretimin kalitesini artırmak ve standartlaştırmak amacıyla INVALSI’ye bazı görevler yüklenmiştir. INVALSI, eğitim koşullarının genel kalitesini, eğitim örgütlerinin görevleriyle uyumlu bir şekilde çalışıp çalışmadığını değerlendirmenin yanı sıra öğrencilerin bilgi ve becerilerini de düzenli olarak kontrol etmektedir. Bir başkan, rehberlik komisyonu ve denetleme kurulundan oluşan INVALSI, 2004 yılında getirilen bir düzenleme ile resmi bir toplum araştırma organı olarak tanınmıştır ve kurumun hazırladığı raporlara göre MUIR tarafından çeşitli faaliyet raporları hazırlanmaktadır (Eurydice, 2010a). Ayrıca Milli Eğitim Konseyi (Consiglio Nazionale della Pubblica Istruzione), eğitim politikalarının planlanması ve denetlenmesi hususunda MIUR'un danışma kurulu olarak görev yapmaktadır (Eurydice, 2010b). İtalya'da eğitim denetmeni olmadan önce öğretmenlikte en az dokuz yıl görev yapmış olma şartı vardır (Gündüz ve Göker, 2014).

Eğitimin finansmanı. 15 Mart 1997 yılında yürürlüğe giren eğitim kanunuyla okullara öğretim yöntemleri, örgütlenme, araştırma, deney yapma ve gelişme gibi konularda özerklik sağlanmasına rağmen mali özerklik verilmemiştir. Eğitim ve yönetime ayrılan düzenli fonlar, devlet tarafından tüm okullara dağıtılmaktadır. Bunun yanında eğitim bölgeleri öğrencilere yemek, ulaşım, ilkokullarda ders kitabı ve fakir öğrencilere burs verme yoluyla çeşitli hizmetler ve destekler sağlamaktadır (Eurydice, 2010a).

İtalya'da zorunlu eğitime kayıt ve katılım ücretsizdir. Bununla birlikte zorunlu eğitim kapsamında olmasa da okul öncesi eğitim de herhangi bir okul harcı alınmamaktadır. Ancak üst ortaöğretim öğrencilerinden okula kayıt ücreti, sınav ücretleri ve laboratuvar/ atölye 
masrafları için ödeme yapılması beklenmektedir. Üniversitelerin finansmanında ise devletin bütçesinden üniversiteler için ayrılan bütçe üç şekilde aktarılır: Üniversitelere ayrılan düzenli ödenekler (Fondo di finanziamento ordinario), üniversite binası ve temel bilimsel ekipman için ayrılan bütçe (Fondo per l'edilizia universitaria e per le grandi attrezzature scientifiche) ve üniversite sisteminin geliştirilmesi için yapılan planlama için ayrılan bütçedir (Fondo per la programmazione dello sviluppo del sistema universitario) (Eurydice, 2010a). Son yıllarda İtalya'da yükseköğretimde öğrenci harçları önemli ölçüde artırlarak önemli bir finansman kaynağı olarak kullanılmaya başlanmıştır (Akça, 2012).

\section{Yöntem}

Alanyazın taraması ile yürütülen bu çalışma, betimsel tarama modelindedir. Literatür taraması araştırma problemi ile ilgili bilginin ve literatürün özeti, sentezi ve incelenmesidir (Balc1, 2013, 75). Tarama modelleri, geçmişte ya da halen var olan durumu var olduğu şekliyle betimlemeyi amaçlayan araştırma yaklaşımlarıdır (Karasar, 2014,77). Literatürde İtalya eğitim sistemini doğrudan konu edinen sınırlı sayıda (Balc1, 2014; Erginer, 2009) basılı kaynak bulunmaktadır. Ayrıca eğitime yaklaşım; kültürel, toplumsal, siyasi birçok faktörün etkisiyle değişimeler göstereceğinden, ülkelerdeki eğitim sistemlerinin zaman içerisinde sistematik şekilde yeniden incelenmesi gereklidir.

$\mathrm{Bu}$ çalışmada, İtalya eğitim sistemine ilişkin en güncel bilgilere ulaşmak amacıyla Eurydice (Avrupa Eğitim Bilgi Ağı) veri tabanı esas alınmıştır. 1980 yılında Avrupa Komisyonu ve üye ülkelerce ortaklaşa kurulan Eurydice, çok çeşitli ulusal eğitim sistemleri ve politikaları üzerine güvenilir ve karşılaştırılabilir yüksek kalitede bilgiler üreterek Avrupa'daki eğitim sistemlerini geliştirmeye yardımcı olmaktadır. Eurydice, 38 ülkedeki Ulusal Birimlerin desteği ile eğitim sistemlerinin, belirli konulara yönelik karşılaştırmaların, göstergelerin ve istatistiklerin tanımlarını yapar. Eurydice Türkiye Birimi 2003 yılında 
kurulmuş olup halen çalışmalarına MEB Strateji Geliştirme Başkanlığı altında devam etmektedir (MEB Strateji Geliştirme Başkanlığı [MEB-SGB], 2016). Eurydice veri tabanının yanı sıra bu çalışmada, eğitim sistemlerine ilişkin ülke raporları, uluslararası kuruluşların raporları, resmi internet siteleri ve konuya ilişkin araştırmacıların yaptıkları çalışmalar da kaynak olarak kullanılmıştır.

\section{Tartışma ve Sonuç}

İtalya Eğitim Sisteminin genel amacı; iyi bir temel kültüre sahip, iş dünyasını tanıyan, yeteneklerine göre demokratik topluma tam bir katılım sağlamış vatandaşlar yetiştirmektir. Bu amaçların Türk Eğitim Sisteminin amaçları ile benzerlik gösterdiği görülmektedir. Bunun yanı sıra Türk Eğitim Sisteminde 1739 sayılı Milli Eğitim Temel Kanununda (1973), Atatürk inkılap ve ilkelerine ve anayasada ifadesi bulunan Atatürk milliyetçiliğine bağl1lık duyma vurgusu yapılmıştır. Ayrıca bu kanuna göre devlet adına tüm eğitim hizmetlerinin yürütülmesi Milli Eğitim Bakanlığının sorumluluğundadır. İtalya'da ise 2000-2001 eğitimöğretim yılından itibaren tüm okullar yönetim, örgütlenme, eğitim, araştırma, deney yapma ve gelişme konularında kısmen de olsa özerklik elde etmişlerdir. Buna rağmen İtalya'da da, tıpkı Türkiye'de olduğu gibi, özel ve resmi tüm okullar devlete bağlıdır ve bütçe belirleme, araştırma enstitülerine yönelik plan yapma ve yabancı okulları denetleme gibi birçok konuda politikalar, merkezden belirlenir (Eurydice, 2010b). İtalya'da, eğitime ilişkin genel hükümleri değiştirme yetkisine sahip olan MUIR'ın, kimi yetkilerini, bölgeler düzeyinde 20 müdürlüğe Türkiye'ye oranla daha fazla devrettiği görülür. Bölgesel yönetimler, AB mevzuatı ve uluslararası yükümlülüklerle çelişmemek kaydıyla, ortak yönetmelik hazırlayabilirler. Görülen o ki, Türkiye ve İtalya Eğitim Sistemlerinde eğitimin amaçları benzerlik gösterse de eğitimde yönetsel yapılanmada farklılıklar bulunmaktadır. 
İtalya'da zorunlu eğitim; beş yıl ilkokul, üç y1l alt ortaöğretim ve üst ortaöğretim eğitiminin ilk iki yılı olmak üzere 10 yıldır ve ücretsizdir. Bununla birlikte lisede ailelerden, çeşitli eğitim materyallerinin alınmasında katkı beklenmektedir ve ders kitapları da ücretsiz değildir. Türkiye'de ise dört y1l ilkokul, dört yıl ortaokul ve dört y1l lise olmak üzere toplam 12 yıl olan zorunlu eğitim boyunca, en azından yasal olarak, öğrencilerden kayıt ve kitap parası alınmamaktadır.

Okul öncesi eğitim kademeleri karşılaştırıldığında; her iki ülkede de okul öncesi eğitimin zorunlu olmadığı ve aynı yaş gurubundaki çocuklara hitap ettiği görülmektedir. İtalya ve Türkiye'de ortak olarak ilkokula başlama yaşı altıdır. İtalya Eğitim Sisteminde ortaöğretimin ilk kademesi olan alt ortaöğretim (junior secondary school, 3 yıl), Türk Eğitim Sistemindeki karşılığı ortaokuldur. Ancak Türkiye'de ortaokul dört yıldır. Her iki ülkede de bu kademeyi bitiren öğrenciler merkezi sınava girerler; ancak İtalya'da lise öğrenimine başlayacak olan öğrencilerin girdiği bu sınavlar, lise giriş sınavı niteliğinde değildir. Öğrenciler, mezun oldukları alt ortaöğretim kademesindeki diploma yeterliklerini belirleyen bir merkezi sınavlara girerler. Türkiye'de ise 17 Eylül 2017 tarihi itibariyle ortaöğretime geçişte belirli derslerden öğrenci başarısını ölçen bir sınav sistemi olan Temel Eğitimden Ortaöğretime Geçiş Sınavının (TEOG) kaldırılacağı Bakanlık yetkililerince açıklanmıştır (www.kamuajans.com). Bu sinavın yerine gelecek olan sistem henüz belirlenmese de bu kararın, öğrencilerin yaşadıkları aşırı sınav stresinden kurtulmaları açısından önemli bir adım olduğu söylenebilir.

İtalya'da mesleki eğitime teşvik amacıyla birinci seviye mesleki eğitim-öğretim okulları kurulmuştur. Bu okullarda öğrencilerden herhangi bir ücret talep edilmez ve eğitim tamamen devlet tarafından finanse edilir. Ayrıca bu eğitimi başarıyla bitiren öğrenciler, lise sonrası eğitim kademesinde bulunan ikinci seviye mesleki eğitime başvuru hakkı elde 
etmektedirler. $\mathrm{Bu}$ okullara katılımın teşvik edilmesi adına bu eğitimin finanse edilmesi ve öğrenciler için esnek geçiş imkânı sunması, meslek liseleri için örnek teşkil etmektedir. Nitekim İtalya'da 2015 yılı itibariyle 20-24 yaş aralığındaki nüfusun \%79,9’u en az lise mezunu iken, bu oran Türkiye'de \%52,6'dır (EC-Eurostat, 2016). Dolayısıyla Türkiye'de liselerde çeşitliliğin daha da artırılarak farklı becerilere ve ilgi alanlarına sahip öğrenciler için cazip hale getirilmesi, lise mezunu oranının artırılması adına önemlidir.

İtalya'da üniversitelere giriş mantığı da ortaokul bitirme sınavına benzer şekildedir. Üniversitelere girişte öğrenciler, Türkiye'dekinin aksine, merkezi bir sınava girmezler. Üniversitenin yapılanması İtalya'da, Türkiye'den farklı olarak üç yıllık genel yeterlik eğitimi ve iki yıllık alan uzmanlığı eğitimi ile sürdürülür. Bu eğitimin sonunda 60 kredilik ders alanlar yüksek lisanslarını tamamlamış olur. Doktora eğitimi ise üç yıl sürmektedir. Ayrıca İtalya'da yükseköğretim finansmanında özel girişimlerin oranı dikkat çekmektedir. İtalya'da yükseköğretime yapılan tüm harcamaların \%66's1 kamu, \%34'ü özel harcamalar iken Türkiye'de yükseköğretime yapılan harcamaların \%80,4'ü kamu \%19,6’sı özel harcamalardır (OECD, 2012).

İtalya'da 20-29 yaş aralığındaki nüfusun yükseköğretime katılma oranı 2014 yılında $\% 24,5$ olarak belirlenmiştir. Türkiye'de ise bu oran $\% 33,8$ 'dir. Türkiye bu oranla, 36 OECD ülkesi arasında yedinci sırada yer almaktadır (OECD, 2014). İtalya'da imzalanan Bologna Bildirgesi ile Avrupa'nın birçok ülkesi, Avrupa yükseköğretim ve araştırma alanının uluslararası ortak bir zeminde yeniden yapılandırılması için bir araya gelmektedir. Türk yükseköğretim kurumları da 2003 yılından bu yana, bu sürece dâhil olmuş ve kendilerini sürece katılan 47 ülkenin yükseköğretim kurumları ile karşılaştırmalı olarak gözden geçirdikleri stratejik bir planlama içinde kurumsal değerlendirme ve akreditasyon süreçlerine girmiştir (Kansu-Yetkiner, 2012). Bu sürecin, uluslararası standartlara uyum gösterme, 
öğrenci ve öğretim üyesi değişimleri ve kültürel etkileşim gibi pek çok konuda Türkiye için önemli bir girişim olduğu söylenebilir. Tablo1'de, İtalya ve Türkiye'deki 25-54 ve 55-74 yaş aralığındaki nüfusun öğrenim durumu verilmiştir.

Tablo 1.

Yaş Aralıklarına ve Eğitim Kademelerine Göre Nüfusun Öğrenim Durumu*

\begin{tabular}{c|ccc|ccc}
\hline Yaş & \multicolumn{3}{|c|}{ 25-54 arası } & \multicolumn{3}{c}{$55-74$ aras1 } \\
\hline $\begin{array}{c}\text { Mezun } \\
\text { olunan } \\
\text { kademe / } \\
\text { ülkeler }\end{array}$ & $\begin{array}{c}\text { Okul öncesi } \\
\text { İlkokul } \\
\text { Alt Ortaöğr. }\end{array}$ & $\begin{array}{c}\text { Lise ve } \\
\text { lise } \\
\text { sonrası }\end{array}$ & Yükseköğretim & $\begin{array}{c}\text { Okul öncesi } \\
\text { İlkokul } \\
\text { Alt Ortaöğr. }\end{array}$ & $\begin{array}{c}\text { Lise ve lise } \\
\text { sonras1 }\end{array}$ & Yükseköğretim \\
\hline İtalya & $\%$ 36,8 & $\% 44,9$ & $\% 18,3$ & $\% 62,3$ & $\% 27,5$ & $\% 10,2$ \\
\hline Türkiye & $\%$ 64,4 & $\% 18,9$ & $\% 16,7$ & $\%$ 85,4 & $\% 7,6$ & $\% 7,1$ \\
\hline
\end{tabular}

* Bilgiler www.eurostat.ec adresinde yer alan 2015 Kasım istatistikleridir.

Tablo1'de görüldüğü gibi İtalya'da orta yaş olarak tanımlanabilecek 25-54 yaş aralığındaki nüfusun neredeyse yarısı $(\% 44,9)$ lise ya da lise sonrası-üniversite öncesi eğitim kademesinden; nüfusun yaklaşı üçte biri kadarı da $(\% 36,8)$ okul öncesi, ilkokul ya da alt ortaöğretim kademesinden mezun olmuştur. Türkiye'de ise lise ve lise sonrası ile üniversite öncesi mezun oranının, İtalya'ya göre oldukça düşük $(\% 18,9)$; okul öncesi ilkokul ve alt ortaöğretim mezun oranının ise oldukça yüksek olduğu $(\% 64,4)$ görülmektedir. Benzer oranlar İtalya lehine, yaşılı olarak tanımlanabilecek yaştaki nüfusun eğitim durumu için de geçerlidir. Özetle; Türkiye İtalya'ya göre; düşük eğitim kademelerinde yüksek; yüksek eğitim kademelerinde düşük oranda mezun vermektedir. Ancak her iki ülke de kendi içinde değerlendirildiğinde, giderek daha yüksek eğitim kademelerinde mezun verdiği söylenebilir.

İtalya'da bütün öğretmenlerin, lisans derecesine sahip olmaları zorunludur. Okul öncesi ve ilkokul düzeyindeki öğretmenler, bir yıllık hizmet-içi eğitimi de kapsayan beş yıllık bir eğitimden geçerken, ortaöğretimde görev yapmak isteyen öğretmenler üç y1llık eğitimin ardından iki yıllık uzmanlık (lisansüstü) eğitimi ve bir yıllık hizmet-içi eğitim (stajyerlik) görürler. Ayrıca okul müdürü olabilmenin yolu; rekabetçi bir sistemde üç yılda bir açılan 
ilanlara başvurarak kültür sınavına ve mesleki sınava girmekten geçer. Bu sınavdan başarılı olan adaylar arasından mülakatta yeterli görülen atanır ancak, görevinin ilk döneminde stajyer olarak eğitim görür. Özellikle ortaöğretim düzeyinde öğretmen olabilmek için aranan uzmanlık eğitimi ön koşulu ile müdürlüğe başlamadan önce müdürlerin bir ön sosyalleşme sürecine tabi tutulmaları, Türk Eğitim Sistemi açısından örnek alınabilir. Türkiye’de öğretmen yeterlikleri yalnızca Kamu Personeli Seçme Sınavında (KPSS) yeterli puanı alma ve mülakat ile sınırlı tutulmuştur. Bunun yanı sıra yeni atanan aday öğretmenlerin deneyimli bir öğretmenin yanında altı aylık bir çıraklık/stajyerlik eğitimi geçirecek olması (Aday Öğretmen Yetiştirme Sürecine İlişkin Yönerge, 2016) olumlu değerlendirilebilir. Türkiye’de okul müdürlerine yönelik İtalya'dakine benzer bir uyum süreci ise bulunmamaktadır. Okul müdürlerinin sosyalleşmeleri çoğu kez tesadüflere bırakılmaktadır (Mazlum, Koç-Başaran ve Balc1, 2016). Okul müdürlerinin yetiştirilmesine ilişsin İtalya'dakine benzer uygulamalar, Türkiye açısından örnek teşkil etmektedir.

\section{Makalenin Bilimdeki Konumu}

Eğitim Bilimleri / Eğitim Yönetimi ve Teftişi Anabilim Dalı

\section{Makalenin Bilimdeki Özgünlüğü}

Eğitim sistemleri, ülkelerin arzu ettikleri toplumsal düzeni oluşturmasında ve geleceği inşa etmesinde hayati öneme sahiptir. Bu doğrultuda ülkeler, eğitim sistemlerini geliştirmek arzusuyla farklı ülkelerin eğitim uygulamalarını da sistematik olarak analiz etmekte, kendi ülkelerindeki eğitim sistemleri için çıkarımda bulunmaktadırlar. Bu çalışmada, sahip olduğu köklü tarih ve kültürel miras ile Avrupa'nın en önemli ülkelerinden birisi olan İtalya'nın eğitim sistemi konu edilmiştir. Karşılaştırmalı eğitim araştırmalarına öncülük eden Kandel'in, dünyanın en önemli laboratuvarlarından birisi olarak gördüğü İtalya eğitim sisteminin incelenmesi, Türk Eğitim Sistemi açısından çıkarımlarda bulunmaya olanak sağlamaktadır. 
Elbette ülkelerdeki eğitim sistemlerinin, toplumsal, kültürel ve siyasi alanlarda yaşanan gelişmelere bağlı olarak gerek makro gerekse mikro düzeyde değişimler geçirmesi de eğitim sistemlerinin belirli zaman aralıklarında yeniden incelenmesini gerekli kılmaktadır.

\section{Kaynakça}

Aday Öğretmen Yetiştirme Sürecine İlişkin Yönerge (2016). T.C. Milli Ĕ̆itim Bakanlı̆̆ Tebliğler Dergisi, 2702, 03.03.2016.

Akça, H. (2012). Yükseköğretimin finansmanı ve Türkiye için yükseköğretim finansman modeli önerisi. Yönetim ve Ekonomi, 19(1), 91-104.

Aktan, O. ve Akkutay, Ü. (2014). OECD ülkelerinde ve Türkiye'de okulöncesi eğitim. Asya Ögretim Dergisi, 2(1), 64-79.

Balcı, A. (2013). Sosyal bilimlerde araştırma: Yöntem, teknik ve ilkeler (10.bask1). Ankara: Pegem A. Yayınc1lık.

Balcı, A. (2014). Karşılaştırmalı eğitim sistemleri. Ankara: Pegem A. Yayıncılık.

CIA (2016). Central Intelligene Agency. The World Factbook. Erişim tarihi: 25.10.2016. https://www.cia.gov/library/publications/the-world-factbook/geos/it.html.

Çelik, V. (1995). Küreselleşme sürecinde Avrupa'da eğitim yönetimi. Eğitim Yönetimi, 1(4).

Çelik, Z. (2012). Bologna süreci'nin Avrupa yükseköğretim sistemi üzerine etkileri. Yüksekögrretim ve Bilim Dergisi, 2(2), 100-105.

DB (2016). Dışişleri Bakanlı̆̆ Elektronik Vize Başvuru Sistemi. Erişim tarihi: 18.02.2016. http://www.mfa.gov.tr/sub.tr.mfa?a791987b-27ea-4f96-a853-31b08d03acab.

EARGED (2009). Türk yetişkin eğitimi sisteminin değerlendirilmesi. Milli Eğitim Bakanlı̆̆ı Araştırma ve Geliştirme Dairesi Başkanlığı.

EC (2015). Organisation of school time in Europe: Primary and secondary general education 2015/16 school year, European Commission. Erişim tarihi: 25.10.2016.

EC-Eurostat (2016a). European Commission, Eurostat. Erişim tarihi: 3.3.2017. http://appsso.eurostat.ec.europa.eu/nui/show.do?dataset=edat_lfs_9903\&lang=en.

EP-Nuffic (2016). The Italian education system described and compared with the Dutch system. Hollanda: Internationalising Education-Nuffic.

Erdoğan, İ. (2003). Karşılaştırmalı eğitim: Türk eğitim bilimleri çalışmaları içinde önemsenmesi gereken bir alan. Türk Ĕ̈itim Bilimleri Dergisi, 1(3), 265-282.

Erginer, A. (2009). Avrupa birliği ĕgitim sistemleri. Ankara: Pegem A. Yayıncılık. 
Eurydice (2006). Quality Assurance in Teacher Education in Europe. Italian EURYDICE Unit.

Eurydice (2010a). Structures of education and training systems in Europe: Italy 2009/2010. Italian EURYDICE Unit.

Eurydice (2010b). Organisation of the education system in Italy 2009/2010. Italian EURYDICE Unit.

Eurydice (2013). Italian Educational System: Owerview (April). Italian EURYDICE Unit.

Gündüz, Y. ve Göker, S. D. (2014). Dünya ölçeğinde eğitim denetmenlerinin iş tanımlarındaki çelişkiler ve rol çatışmaları. Abant İzzet Baysal Üniversitesi Ĕ̆itim Fakültesi Dergisi, 14(2), 155-174.

http://www.kamuajans.com/kultur-sanat/teog-sinavi-kaldirildi-bakan-yilmaz-in-aciklamalarih515339.html. Erişim tarihi: 21.09.2017.

İGEME (2011). İhracatı Geliştirme Etüd Merkezi, İtalya Ülke Raporu (yayına hazırlayan, P. Özpak). Ankara: T. C. Başbakanlık Dış Ticaret Müsteşarlığı.

Kansu-Yetkiner, N. (2012). Bologna süreci deneyimi ve çeviri eğitimi: Firsatlar, sorunlar. T.C. Avrupa Birliği Bakanlı̆̆ Çeviri Platformu.

Karasar, N. (2014). Bilimsel araştırma yöntemi (27.bask1). Ankara: Nobel Yayıncılık.

Korkut, F. ve Mızıkacı, F. (2008). Avrupa Birliği, Bologna süreci ve Türkiye'de psikolojik danışman eğitimi. Kuram ve Uygulamada Ĕ̆itim Yönetimi, 53, 99-122.

LPI (2016). Legatum Prosperity Index (Legatum Refah Endeksi). Erişim tarihi 12.03.2016. http://www.prosperity.com/rankings.

Mazlum, M.M., Koç-Başaran, Y., ve Balc1, A. (2016). Okul Müdürlerinin Örgütsel Sosyalleşme Yaşantıları. Sözlü bildiri, III. Uluslararası Avrasya Eğitim Araştırmaları Kongresi, Muğla.

MEB [Milli Eğitim Bakanlığı] (2010). Ittalya Eğitim Sistemi (yayına hazırlayan, R. Altın). Ankara: Mesleki ve Teknik Eğitim Genel Müdürlüğü.

MEB [Milli Eğitim Bakanlığı] (2011). 2011 Denklik Kılavuzu. Ankara: Talim ve Terbiye Kurulu Başkanlığı.

MEB-SGB (2016). Milli Eğitim Bakanlığı Strateji Daire Başkanlığı. Eurydice Birimi. Erişim tarihi: 01.02.2016. http://sgb.meb.gov.tr/eurydice/index.htm.

Milli Eğitim Temel Kanunu (1973). T.C. Resmi Gazete, 14574, 24.6.1973. 
OECD (2012). Spending on tertiary education (indicator). doi: 10.1787/a3523185-en. Erişim tarihi: 5.11.2016. https://data.oecd.org/eduresource/public-spending-on-education. Htm\#indicator-chart.

OECD (2014). Enrolment rate (indicator). doi: 10.1787/1d7e7216-en. Erişim tarihi: 21.09.2017. https://data.oecd.org/eduatt/enrolment-rate.htm.

Sağlam, M. (2004). Avrupa birliği ülkelerinde yükseköğretime giriş sistemi. XIII. Ulusal Eğitim Bilimleri Kurultayl, İnönü Üniversitesi, Eğitim Fakültesi, (6-9 Temmuz) Malatya.

Sart, H., Ala, H., Yazlık, Ö. ve Yılmaz, F. K. (2004). Türkiye kaynaştırma eğitiminde nerede?: eğitimciye öneriler. XIII. Ulusal Eğitim Bilimleri Kurultayı, İnönü Üniversitesi, Eğitim Fakültesi, (6-9 Temmuz) Malatya.

SC (2005). Socrates Comenius. Latınitas or Europa from present to past, from past to present: The Italian education system. School Project 2004/2005.

SR (1947). Senato della Repubblica. Constitution of the Italian Republic. Erişim tarihi:18.02.2017. https://www.senato.it/documenti/repository/istituzione/costituzione _inglese.pdf.

Toprak, L. (2009). Okul öncesi eğitimi ve Diyarbakır. Dicle Üniversitesi Sosyal Bilimler Enstitüsü Elektronik Dergisi, 1(1), 70-83.

UNESCO (2012). United Nations Educational, Scientific and Cultural Organization, World Data on Education (VII Edition, July). UNESCO-IBE.

UNIDAV (2013). Universita Telematika Leonardo da Vinci, The English language in the Italian education system. Erişim tarihi: 01.11.2016. http://www.adameurope.eu/prj/11815/prj/Italy_SWOT_Analysis.pdf.

Yılmaz, K. (2014). İtalya Eğitim Sistemi. Karşılaştırmalı Eğitim Yönetimi (ed. A. Balcı Ankara: Pegem A. Yayıncılık.

\section{Summary}

Problem Statement: Countries need to develop in terms of economic, social, political and cultural factors in order to sustain their existence for many years by raising the qualified human power they need. Undoubtedly, education is one of the most important tools for achieving a sustainable development in all areas. In this context, countries are systematically going into the effort to organize educational activities in order to build the desired social 
order and build the future. Besides, countries are investigating and analyzing the education systems of various countries in order to develop their education systems, make inferences for their own practices. This demonstrates the importance of examining educational systems with a comparative perspective among countries. In addition, since the approach to education changes with the effects of cultural, social and political factors, it is necessary to systematically review the educational systems of the countries over time.

Italy, where the foundations of contemporary republican regimes have been laid; with its history, civilizations, political developments, tourism, industry, fashion, cuisine, architecture, art, literature and universities, has become one of the most important countries in Europe. With its deep-rooted history and cultural heritage, Italy is worth to investigate in the field of education as it is in many areas.

Purpose of the Study: The aim of this study which is in the descriptive scanning model with literature review is to introduce the Italian education system, to analyze it in comparison with the Turkish education system and make inferences. Accordingly, the geographical, social and political structure of Italy has been explained at first; Italian education system has been analyzed by considering the administrative and school structure and the process aspect.

Method(s): This study, conducted by literature review, is a descriptive scanning model. The information obtained in this way has been transferred paying regard to the managerial and school structure and the process dimension. The Legatum Prosperity Index was taken as the reference for determining Italy as the country to study. The development index set by the Legatum Institute, the think-tank; is determined by many fields such as economy, social capital, education, security and general development of countries. In the study, Eurydice (European Education Information Network) database was taken as the basis for achieving the most up-to-date information on the Italian education system. Established in 1980 by the 
European Commission and Member States, Eurydice is helping to develop educational systems in Europe by producing reliable and comparable high quality information on a wide range of national education systems and policies. Besides in this study, country reports on education systems, reports of international organizations, official internet sites and studies conducted by researchers related to the topic were also used as resources.

Findings and Discussions: The general aim of the Italian Education System shows a great similarity with the aims of the Turkish Education System. In addition, in the National Education Basic Law no 1739 of Turkish Education System, it is emphasized loyalty to Ataturk nationalism, which has the expression of Atatürk's reforms and principles and the constitution. It is also in the charge of the Ministry of National Education to conduct all educational services on behalf of the state under this law. Although the aims of education both in Turkey and Italy are similar, it is seen that the Italian education system has a relatively autonomous management structure. Students who finish secondary school in both countries enter the central examinations. However, in Italy these exams are not entrance examinations to high school for students who will start high school education. Students enter a central exam that determines their diploma qualifications at the lower secondary level they graduate. In Turkey, students are placed to the high schools according to their exam scores and in Turkey the type of high school that students can choose is limited compared to Italy. In Italy students attending to the universities do not enter a centralized examination. First level vocational education schools have been established in Italy to promote vocational education. No fees are requested from students in these schools and education is financed entirely by the state. In addition, students who have successfully completed this training obtain the second level vocational training right after the high school education level. 
In Italy, it is imperative that all teachers have a degree of profession. In order to teach in kindergartens and elementary schools, there is a requirement to receive a five-year education, one period internship. In addition to this, teachers who want to work in secondary education need to take a two year post-graduate education and one year internship education. Also, the way to be a school principal; it goes through the competition examination and professional practice by applying to the announcements made every three years in a competitive system. Candidates who are successful in this examination are assigned to the interview but are trained as interns during the first term of the assignment.

Conclusions and Recommendations: In Italy, the variety of high school type, vocational high school attendance and high school graduation rate are obviously different according to Turkey. Examination sense in Italy predicts that the student will be able to successfully complete the section he is currently pursuing rather than being competed with his competitors in order to qualify for the new level of education. In addition, to encourage participation in vocational schools, financing this training and providing flexible transitional arrangements for students serve as a model for vocational high schools. There is no orientation period for principals in Turkey similar to those in Italy. The socialization of school principals is often left to chance. In addition, teacher qualifications in Turkey are limited to obtaining sufficient scores only in an examination named KPSS. Similar practices in Italy to determine the precondition for being a school principal and teacher are examples of Turkey.

Keywords: Italian education system, Turkish education system, comparative education 